Wiktor Szymborski

UNIWERSYTET JAGIELLOŃSKI

\title{
Źródła do historii dominikańskiego studium generale w Krakowie w epoce nowożytnej. Stan badań i perspektywy badawcze
}

Poniższy tekst przedstawia skrótową charakterystykę wybranych najważniejszych źródeł, przechowywanych w Archiwum Polskiej Prowincji Dominikanów w Krakowie, do dziejów krakowskiego studium generale w epoce nowożytnej ${ }^{1}$. W tym celu w pierwszej kolejności zostanie zasygnalizowana kwestia stanu badań, w dalszej części zaprezentowane zostaną uwagi odnoszące się do najważniejszych źródeł, a całość rozważań zamknie lista postulatów badawczych związanych z proponowanym tematem badań dominikańskiego studium generale. Ramy chronologiczne niniejszej analizy zawężono do okresu XVI-XVII wieku, o ile jednak cezura początkowa jasno wynika ze stanu badań tego tematu, o tyle przyjęcie roku 1700 za koniec rozważań wynika z założenia kolejnego zakonnego studium generale na terenie polskiej prowincji dominikańskiej - Warszawy².

${ }^{1}$ Niniejszy tekst nie powstałby, gdyby nie inspiracja ze strony Ojca dr. Tomasza Gałuszki OP, który kilka lat temu zwrócił mi uwagę na kwestie dominikańskiego szkolnictwa. Autor winien jest także gorące podziękowania Ojcu Markowi Miławickiemu OP za liczne cenne uwagi oraz możliwość wspólnego przygotowania tekstu poświęconego krakowskim regensom. Osobne podziękowania należą się Ojcu Ireneuszowi Wysokińskiemu za wyjątkowe cierpliwe udostępnianie bezcennych zbiorów Archiwum Polskiej Prowincji Dominikanów w Krakowie. Tekst w języku angielskim został złożony do druku w pracy zawierającej materiały z konferencji pt. Transformation of Central European Cities in Historical Development (Košice, Miskolc, Opava and Krakow) from the Middle ages to the end of 18th century, która odbyła się w Koszycach w dniach 28-29 VI $2012 \mathrm{r}$.

2 Por. R. Świętochowski OP, Szkolnictwo teologiczne dominikanów. W: Dzieje teologii katolickiej $w$ Polsce. Pod red. M. Rechowicza. T. 2: Od odrodzenia do oświecenia. Cz. 2: Teologia neoscholastyczna i jej rozwój $w$ akademiach $i$ szkołach zakonnych. Lublin 1975, s. 252. 
Badania nad środowiskami zakonnymi cieszą się nieustannym zainteresowaniem naukowców. Analizowane są zarówno aspekty związane z gospodarką, osadnictwem, kulturą intelektualną oraz dziejami szkolnictwa. Niezwykle cenny wkład stanowią materiały z konferencji organizowanych pod egidą prof. dr hab. Anny Pobóg-Lenartowicz oraz prof. dr. hab. Marka Derwicha. Warte odnotowania są prace Jerzego Flagi ${ }^{3}$, Henryka Gapskiego ${ }^{4}$ odnoszące się do krakowskich środowisk zakonnych. Natomiast w odniesieniu do historii klasztoru dominikanów w okresie nowożytnym można zaobserwować znaczący spadek zainteresowania badaczy, którzy w swych pracach przede wszystkim poruszali zagadnienie lokacji oraz początkowych dziejów tego zakonu5. Tendencja ta wi-

${ }^{3}$ J. Flaga, Formacja i kształcenie duchowieństwa zakonnego w Rzeczypospolitej w XVII i XVIII wieku. Lublin 1998; tenże, Uczoność zakonów w II połowie XVIII wieku. W: Christianitas et cultura Europae. Księga jubileuszowa Profesora Jerzego Kłoczowskiego. Pod red. H. Gapskiego. Cz. 1. Lublin 1998, s. 265-27; tenże, Ankieta zakonna nuncjusza G. Garampiego z lat 1773/74 jako podstawa źródłowa do badań nad studiami zakonnymi i ich organizacją. „Roczniki Teologiczno-Kanoniczne" T. 36: 1989, z. 4, s. 35-44; tenże, Formacja kandydatów do zakonów w XVII i XVIII wieku. „Roczniki Humanistyczne” T. 38: 1990, z. 2, s. 79-117; tenże, Z problematyki formacji intelektualnej kandydatów do zakonów w XVIII wieku. Organizacja i funkcjonowanie studiów retoryki. „Zeszyty Naukowe Katolickiego Uniwersytetu Lubelskiego” T. 35: 1992, nr 1/2 (137-138), s. 62-84; tenże, $Z$ problematyki funkcjonowania studiów zakonnych w XVII i XVIII w. „Roczniki Humanistyczne” T. 39/40: 1991/1992, z. 2, s. 81-96; tenże, Organizacja zakonnych studiów filozoficzno-teologicznych w XVII i XVIII w. „Roczniki Humanistyczne” T. 42: 1994, z. 2, s. 97-122; tenże, Sposób powoływania lektorów w studiach zakonnych $w$ XVII i XVIII wieku oraz przystugujące im przywileje. „Roczniki Teologiczne" T. 42: 1995, z. 4, s. 43-63.

${ }^{4}$ H. Gapski, Profesi dominikańscy konwentu krakowskiego w latach 1509-1650 (Na podstawie księgi profesji). Studia nad historia dominikanów w Polsce 1222-1972. Pod red. J. Kłoczowskiego. T. 1. Warszawa 1975, s. 647-686; tenże, Rekrutacja do zakonów męskich w Polsce w końcu XVI $i$ w pierwszej połowie XVII wieku na przykładzie krakowskiego ośrodka zakonnego. Lublin 1987; tenże, Klasztory krakowskie w końcu XVI $i$ w pierwszej połowie XVII w. Analiza przestrzenna środowisk zakonnych. Lublin 1993.

${ }^{5}$ Literaturę zestawia i omawia J. Kłoczowski, Wspólnoty zakonne w średniowiecznej Polsce, Lublin 2010; zob. też J. A. Spież, Badania nad przeszłością dominikanów w średniowiecznej Polsce. Próba bilansu. W: Dzieje dominikanów w Polsce XIII-XVIII wiek. Historiografia i warsztat badawczy historyka. Pod red. H. Gapskiego, J. Kłoczowskiego, J. A. Spieża. Lublin 2006, s. 27-51; H. Gapski, Badania nad przeszłością dominikanów w Rzeczypospolitej Obojga Narodów. Próba bilansu. W: tamże, s. 53-69; P. Krupa, Wykształcenie filozoficzne dominikanów polskich w XVIII stuleciu. „Theses ex universa philosophia” Ludwika de Mathy OP (1753). W: Dominikanie: Gdańsk - Polska - Europa. Materiały $z$ konferencji międzynarodowej pt.: „Gdańskie i europejskie dziedzictwo Zakonu Dominikanów w dziejach Gdańska", zorganizowanej przez Klasztor OO. Dominikanów w Gdańsku, Instytut Historii Uniwersytetu Gdańskiego, Instytut Archeologii Uniwersytetu Warszawskiego, z okazji 775-lecia powstania klasztoru św. Mikołaja w Gdańsku (9-10 maja 2002). Pod red. D. Dekańskiego, 
doczna jest także w podejmowanych badaniach nad dziejami zakonnego systemu kształcenia ${ }^{6}$. Funkcjonowanie krakowskiego studium generale w okresie średniowiecza doczekało się licznych i cennych opracowań, na uwagę zasługują studia Krzysztofa Kaczmarka, Macieja Zdanka ${ }^{8}$, Jerzego Kłoczowskiego9, Pawła

A. Gołembnika, M. Grubki OP. Gdańsk-Pelplin 2003, s. 90; J. Kłoczowski, Zakonnicy dominikańscy 1772-1971/2. „Sprawozdania Towarzystwa Naukowego Katolickiego Uniwersytetu Lubelskiego” T. 21: 1973, s. 77-82; tenże, Rozwój dominikanów w państwie polsko-litewskim w XVII-XVIII wieku. „Sprawozdania Towarzystwa Naukowego Katolickiego Uniwersytetu Lubelskiego” T. 19: 1971, s. 7076; K. Górski, Dzieje życia wewnętrznego dominikanów polskich w XVI-XVIII wieku (problematyka iźródła). Tamże, s. 76-84; R. Świętochowski OP, Źródła do dziejów nowożytnych Zakonu Kaznodziejów w Polsce. Tamże, s. 84-91; P. Kielar OP, Dominikanie ślascy w okresie reformacji. Tamże, s. 91-99; zob. też zestawienie literatury w pracy P. Stolarski, Friars on the Frontier. Catholic Renewal and the Dominican Order in Southeastern Poland, 1594-1648. Burlington 2010, s. 217-251.

${ }^{6}$ Omówienie dyskusji pomiędzy tezami Pawła Kielara, Jerzego Kłoczowskiego oraz Macieja Zdanka odnośnie do fundacji krakowskiego studium zawiera szkic - K. Kaczmarek, Wokół historiograficznych sporów o początki dominikańskiego studium generalnego w Krakowie. „Przegląd Tomistyczny" T. 16: 2010, s. 13-24; odnośnie do genezy studium generale zob. też ustalenia J. Turek, Regens krakowski Jan $z$ Soboru Pizańskiego w świetle dwóch traktatów Jana Falkenberga. Tamże, s. 43-57. Tematyka historii szkolnictwa dominikańskiego była wielokrotnie charakteryzowana przez badaczy. Zob. szerzej K. Kaczmarek, Studia nad historią dominikanów w Polsce. Stan i kierunki badań - głos w dyskusji. W: Dzieje dominikanów w Polsce XIII-XVIII wiek..., s. 139-147; zob. też krótki przegląd literatury odnośnie do tego zagadnienia J. A. Spież, Badania nad przeszłością dominikanów..., s. 43-45; K. Stopka, Szkoła zakonna w Polsce średniowiecznej jako problem badawczy. W: Klasztor w kulturze średniowiecznej Polski. Pod red. A. Pobóg-Lenartowicz, M. Derwicha. Opole 1995, s. 52-54. Na uwagę zasługuje także artykuł Anny Zajchowskiej ukazujący niemal nieobecny w literaturze temat życia codziennego krakowskiego studium. Zob. A. Zajchowska, Czy w dominikańskim Studium Generale $w$ Krakowie urządzano otrzęsiny? Collatio de beanis w rękopisie LXV6 z Archiwum Polskiej Prowincji Dominikanów w Krakowie. „Przegląd Tomistyczny” T. 16: 2010, s. 59-75.

7 K. Kaczmarek, Szkoły i studia polskich dominikanów w okresie średniowiecza, Poznań 2005; tenże, Od studenta do magistra. Jak długo trwały studia polskich dominikanów w XV wieku? „Biuletyn Historii Wychowania” T. 1/2: 1997, s. 10-21; tenże, Jeszcze o lektorach i studentach w średniowiecznej prowincji polskich dominikanów oraz ich szkołach $w$ Krakowie $i$ we Lwowie. „Nasza Przeszłość" T. 88: 1997, s. 59-89; tenże, Głos w dyskusji nad początkami studium generalnego dominikanów w Krakowie. Tamże, T. 91: 1999, s. 77-100; zob. też tekst zawierający charakterystykę stanu badań nad źródłami dotyczącymi zakonu braci kaznodziejów w Polsce - tenże, Nekrolog Dominikanów Poznańskich. „Studia Źródłoznawcze” T. 43: 2005, s. 125-128.

${ }^{8}$ M. Zdanek, Szkoły i studia dominikanów krakowskich w średniowieczu, Warszawa 2005; tenże, Regensi dominikańskiego studium generalnego w Krakowie do 1596 r. „Przegląd Tomistyczny” T. 16: 2010, s. 77-124.

9 Zbiór artykułów poświęconych szkolnictwu dominikańskiemu został zebrany w pracy J. Kłoczowski, Polska Prowincja Dominikańska w średniowieczu i Rzeczypospolitej Obojga (wielu) Narodów. Poznań 2008, s. 231-335. 
Kielara $\mathrm{OFP}^{10}$, Jerzego B. Korolca ${ }^{11}$, Wacława Bucichowskiego ${ }^{12}$. Trend ten jest widoczny również wśród badaczy zachodnioeuropejskich, którzy koncentrują się na najwcześniejszych dziejach zakonnych ${ }^{13}$.

Nowożytne losy studium, jak dotąd, nie były przedmiotem szerokiej analizy. Najwięcej uwagi poświęcił im Robert Świętochowski OP ${ }^{14}$, były także wzmianko-

${ }^{10} \mathrm{P}$. Kielar, Studia nad kultura szkolną i intelektualna dominikanów prowincji polskiej w średniowieczu. W: Studia nad historia dominikanów w Polsce 1222-1972..., T. 1, s. 271-517; tenże, Organizacja szkolnictwa dominikańskiego w XIV w. „Studia Philosophiae Christianae” R. 5: 1969, nr 1, s. 304-318.

${ }^{11}$ J. B. Korolec, Studia nad szkolnictwem dominikańskim w Polsce. W: Studia nad historia dominikanów w Polsce 1222-1972..., T. 1. s. 517-543; tenże, Lista lektorów dominikańskich prowincji polskiej w XIII-XIV wieku. „Materiały i Studia Zakładu Historii Filozofii Starożytnej i Średniowiecznej” T. 2: 1962, s. 196-213; tenże, Lista lektorów i szkół dominikańskich w Polsce XV w. Tamże, T. 4: 1965, s. $276-$ 334; tenże, Struktura organizacyjna szkół dominikańskich. Tamże, T. 9: 1968, s. 3-25; tenże, Wstęp do badań nad życiem umysłowym dominikanów wrocławskich. Tamże, T. 8: 1974, s. 126-159; tenże, Studium generale dominikanów klasztoru Świętej Trójcy w Krakowie. W: Dominikanie w środkowej Europie w XIII-XV wieku. Pod red. J. Kłoczowskiego, J. A. Spieża OP. Poznań 2002, s. 173-186.

${ }_{12} \mathrm{~W}$. Bucichowski, Lista lektorów dominikańskich prowincji polskiej od erygowania prowincji (1225) do roku 1525. „Przegląd Tomistyczny” T. 6/7: 1997, s. 45-233.

${ }^{13}$ Zob. M. Mulchahey, "First the Bow is Bent in Study...” Dominican Education before 1350. Toronto 1998; zob. też zbiór studiów Studio e Studi. Le scuole degli ordini mendicanti tra XIII e XIV secolo. Atti del XXIX Convegno internazionale Assisi, 11-13 ottobre 2001. Spoleto 2002; Praedicatores/Doctores Lo Studium generale dei fratri Predicatori nella cultura bolognese tra il'2oo e il'3oo. Ed. R. Lambertini. „Memorie Domenicane” T. 39: 2008; L. E. Boyle, Notes on the Education of the "Fratres communes” in the Dominican Order in the Thirteenth Century. W: Xenia medii aevi historiam illustrantia oblata Thomae Kaeppeli. Ed. R. Creytens, P. Künzle. Vol. 1. Roma 1978, s. 249-267; W. A. Hinnebusch OP, The History of the Dominican Order. Intellectual and Cultural Life to 1500. Vol. 2. New York 1973; zob. też charakterystykę badań szkolnictwa dominikańskiego - K. Kaczmarek, Szkoły i studia polskich dominikanów w okresie średniowiecza..., s. 37-39.

${ }^{14}$ R. Świętochowski OP, Szkolnictwo teologiczne dominikanów..., s. 211-287; R. Świętochowski OP, A. Chruszczewski, Polonia Dominicana apud extraneos. 1520-180o. W: Studia nad historia dominikanów w Polsce 1222-1972. Pod red. J. Kłoczowskiego. T. 2. Warszawa 1975, s. 467-572; warto nadmienić, że część prac ojca Świętochowskiego po dziś dzień pozostaje w maszynopisie przechowywanym w Archiwum i Bibliotece klasztoru krakowskiego, w tym szczególnie przydatny przy zajmowaniu się prozopografią dominikańską Słownik biograficzny OO. Dominikanów w Polsce A-Z, Kraków 1979, mszps w zbiorach Biblioteki dominikańskiej w Krakowie; zob. też uwagi K. Kaczmarek, Szkoły i studia polskich dominikanów w okresie średniowiecza..., s. 45; wykaz literatury dotyczącej studium w okresie nowożytnym zawarty został w: M. Miławicki OP, W. Szymborski, „Vir sapientiae et morum probitate clarus”. Regensi studium generalnego polskiej prowincji dominikanów w XVII w. „Przegląd Tomistyczny” T. 16: 2010, s. 127-130; zob. też uwagi - K. Kaczmarek, Szkoły i studia polskich dominikanów w okresie średniowiecza..., s. 39-50; H. Gapski, Badania nad przeszłościa dominikanów..., s. 61-62; K. Ożóg, Uwagi o potrzebach i perspektywach w zakresie 
wane $\mathrm{w}$ toku opracowywania syntetycznych rozpraw poświęconych kształceniu duchowieństwa w Rzeczypospolitej w XVII i XVIII wieku. W odniesieniu do prac poruszających tematykę związaną z kręgiem zakonnym można zaobserwować wyraźną dominację publikacji omawiających najwcześniejsze dzieje ${ }^{15}$. Kwerenda w literaturze poświęconej zakonowi dominikańskiemu wykazała, że badacze swą uwagę koncentrowali na studiach podejmowanych przez dominikanów na uniwersytetach $\mathrm{w}$ okresie średniowiecznym i nowożytnym (studia opublikowane w najważniejszych periodykach zajmujących się dziejami zakonu braci kaznodziejów „Archivum Fratrum Praedicatorum”"16, „Archivo Dominicano” ${ }^{17}$ i „Mémoire

badań nad dziejami dominikanów prowincji polskiej w średniowieczu ze szczególnym uwzględnieniem ich kultury intelektualnej i duchowej. W: Dzieje dominikanów w Polsce XIII-XVIII wiek..., s. 111n.; warto podkreślić, że kwestia funkcjonowania nowożytnych studiów zakonnych jest bardzo słabo rozpoznana w literaturze. Zob. przykładowe prace odnoszące się do studium klasztornego w Lublinie: J. A. Wadowski, Kościoły lubelskie na podstawie źródeł archiwalnych. Kraków 1907, s. 283-293, tematykę tę porusza także S. Jarszewski, Dominikańscy przeorzy konwentu św. Stanisława B. M. w Lublinie 1582-166o. Lublin 2001, s. 113-121.

${ }^{15}$ Spośród publikacji polskich badaczy na uwagę zasługują studia A. Wróblewskiego ogłoszone w „Przeglądzie Tomistycznym”, poświęcone nowożytnemu szkolnictwu w prowincji litewskiej. Zob. Personel nauczycielski szkół dominikańskich prowincji litewskiej na przełomie XVIII i XIX wieku. „Przegląd Tomistyczny” T. 1: 1984, s. 335-365; tenże, Nauczanie w średnich szkołach dominikańskich na Litwie na przełomie XVIII i XIX wieku. „Przegląd Tomistyczny” T. 3: 1987, s. 343-370.

${ }^{16}$ A. de Meyer OP, Fratres Praedicatores in Universitate Lovaniensi. „Archivum Fratrum Praedicatorum" T. 4: 1934, s. 271-278; S. Vallaro OP, I Domenicani in un documento antico dell'Università di Torino. Tamże, T. 6: 1936, s. 39-98; G. M. Löhr OP, Die älteste Theologische Promotionsordnung der Kölner Universität. Tamże, T. 9: 1939, s. 214-222; tenże, Breslauer Dominikaner des 15. Jahrhunderts auf auswärtigen Hochschulen. Tamże, T. 13: 1943, s. 162-178; tenże, Die Dominikaner an der Universität Heidelberg. Tamże, T. 21: 1951, s. 272-293; tenże, Die Dominikane an der Ostdeutschen Universitäten Wittenberg. Frankfurt-Oder, Rostock und Greifswald. Tamże, T. 22: 1952, s. 294-316; tenże, Die Dominikaner an den Universitäten Erfurt und Mainz. Tamże, T. 23: 1953, s. 236-274; C. Mercier OP, J. Toravel OP, Les Dominicains du Collège Général Saint-Jacques à Paris de 1759 à 179o. Tamże, T. 40: 1970, s. 375-397; R. Creytens OP, Il registro dei maestri degli studenti dello studio domenicano di Bologna (1576-1604). Tamże, T. 46: 1976, s. 25-114; M. O'Carroll SND, The Educational Organisation of the Dominicans in England and Wales 1221-1348: A Multidisciplinary Approach. Tamże, T. 50: 1980, s. 23-62; L. Airaghi, Studenti e professori di S. Eustorgio in Milano dalle origini del convento alla meta del XV secolo. Tamże, T. 54: 1984, s. 355-380; P. Zutshi, R. Ombres OP, The Dominicans in Cambridge 1238-1538. Tamże, T. 60: 1990, s. 313-373; M. Vandecasteele, A Scholarly Book Collection Claimed by the Dominicans of Ghent (Flanders) in 1349. Tamże, T. 78: 2008, s. 31-49.

${ }_{17}$ A. M. Rodríguez Cruz OP, Dominicos en la Universidad de Salamanca. „Archivo Dominicano" T. 5: 1984, s. 91-118; tenże, Dominicos en la Universidad de Salamanca (I-2). Tamże, T. 6: 1985, s. 5-22; tenże, Dominicos en la Universidad de Salamanca (I-3). Tamże, T. 7: 1987, s. 49-58; A. Melcón OP, M. Beuchot OP, Presencia Dominicana en la Universidad de México. Tamże, T. 10: 1989, 
Dominicaine. Histoire - Documents - Vie dominicaine" ${ }^{18}$ ), a nie na przedstawieniu szkolnictwa zakonnego czy prozopografii klasztornej w tym okresie ${ }^{19}$.

Przegląd źródeł dotyczących krakowskiego studium wypada zacząć od pozycji wydanych drukiem, w dalszej części przedstawione zostaną najważniejsze źródła rękopiśmienne. Do najważniejszych źródeł ogłoszonych drukiem należy zaliczyć akta kapituł generalnych ${ }^{20}$. Na ich podstawie można sformułować charakterystykę systemu kształcenia oraz zmiany, jakim podlegał, jak miało to miejsce przykładowo na początku XIV i XV wieku, czy w okresie późniejszym w związku z aktywnością Sykstusa Fabriego ${ }^{21}$. Co istotne, w aktach kapituł znajdują się dane odnośnie do liczby magistrów czy bakałarzy ustalonych dla poszczególnych prowincji, jak również asygnacje wykładowców oraz stu-

s. 81-138; A. O. Sánchez, Las tercias de Valcuevo La Universidad de Salamanca y el Convento de San Esteban de poder a poder. Tamże, T. 21: 2000, s. 237-258; C. Palomo Iglesias OP, Los Dominicos y su labor universitaria en Plesencia. Convento de San Vicente Ferrer. Tamże, T. 25: 2004, s. 20-35; A. M. Rodríguez Cruz OP, Dominicos en la Universidad de Salamanca (I-4). Tamże, p. 127-136.

18 Zob. szerzej numer poświęcony szkolnictwu - „Mémoire Dominicaine. Histoire - Documents - Vie dominicaine” T. 3: 1993. Zob. także J. K. Farge, Les Dominicains et la faculté de théologie de Paris. „Mémoire Dominicaine. Histoire - Documents - Vie dominicaine” T. 12/1: 1998, s. 21-39; M. Mulchahey, Praedicatores/Doctores. Lo Studium generale dei fratri Predicatori nella cultura bolognese tra il'20o e il'30o. „Mémoire Dominicaine. Histoire - Documents - Vie dominicaine” T. 39: 2008, s. 17-31.

19 Spośród ważniejszych publikacji przedstawiających dzieje zakonu dominikanów w okresie nowożytnym zob. The English Dominican Province (1221-1921). London 1921; G. Anstruther, A Hundred Homeless years, English Dominicans 1558-1658. London 1958; J. D. Levesque, Les Frères Prêcheurs de Lyon, Notre Dame de Confort 1218-1789. Lyon 1978; H. Fenning, The Irish Dominican Province, 1698-1797. Dublin 1990; T. S. Flynn, The Irish Dominicans 1536-1641. Dublin 1993; A. Ross, Scottish Blackfriars in the Seventeenth Century. Glasgow 1972.

${ }^{2 \circ}$ Acta Capitulorum Generalium Ordinis Praedicatorum. Vol. 4: Ab anno 1501 usque ad annum 1553. Ed. A. Frühwirth. Romae 1901; Acta Capitulorum Generalium Ordinis Praedicatorum. Vol. 5: Ab anno 1558 usque ad annum 1603. Ed. A. Frühwirth. Romae 1901; Acta Capitulorum Generalium Ordinis Praedicatorum. Vol. 6: Ab anno 1601 usque ad annum 1628. Ed. A. Frühwirth. Romae 1902; Acta Capitulorum Generalium Ordinis Praedicatorum. Vol. 7: Ab anno 1629 usque ad annum 1656. Ed. A. Frühwirth. Romae 1902; Acta Capitulorum Generalium Ordinis Praedicatorum. Vol. 8: Ab anno 1670 usque ad annum 1721. Ed. A. Frühwirth. Romae 1903.

${ }^{21}$ Odnośnie do kwestii prawnych poruszanych podczas obrad kapituł generalnych i prowincjalnych zob. J. Kłoczowski, Kapituły Polskiej Prowincji Dominikańskiej w XVII wieku. W: tenże, Polska Prowincja Dominikańska w średniowieczu..., s. 431n.; tenże, Zakon dominikański i poczatki wyższego szkolnictwa na ziemiach polskich. W: tenże, Polska Prowincja Dominikańska w średniowieczu..., s. 237; P. Krupa, Wykształcenie filozoficzne..., s. 91-92; zob. też K. Stopka, Szkoła zakonna..., S. 56. 
dentów do studiów generalnych ${ }^{22}$. Lektura akt kapituł generalnych umożliwi prześledzenie nominacji na najwyższe urzędy krakowskiego studium - regensów i zwierzchników studium, jak i głównych wykładowców. Warto jednakże pamiętać, że kapituła generalna mogła zrezygnować z tego prawa i przekazać te kompetencje prowincjałowi ${ }^{23}$. Dzięki informacjom zawartym w aktach kapituł można ustalić nazwiska zakonników wysyłanych z poszczególnych prowincji na dalsze studia za granicą ${ }^{24}$.

Równie ważne znaczenie posiadają akta kapituł polskiej prowincji. Bezcennych informacji dostarczają akta ogłoszone drukiem przez ojca Fabiana Madurę ${ }^{25}$. W zbiorach biblioteki krakowskiego konwentu w maszynopisie pozostają kolejne tomy tego wydawnictwa, zawierające kolejne akta kapitulne, których opracowaniu ojciec Madura poświęcił lata pracy ${ }^{26}$. Z punktu widzenia badań składu społecznego studium generale zapisy wspomnianych akt mają wyjątkowe znaczenie. To właśnie w oparciu o nie można sporządzić wykazy osób mianowanych na urzędy. A jak pokazał przykład opracowania katalogu regensów, możliwa staje się także korekta podstawowego źródła rękopiśmiennego do dziejów studium generale, jakim jest Liber studii. O wadze i znaczeniu tak ważnego źródła, jakim są akta kapituł, najdobitniej świadczą liczne studia autorstwa Jerzego Kłoczowskiego, który w oparciu o ich wnikliwą lekturę formułował cenne wnioski odno-

${ }^{22}$ Zob. K. Kaczmarek, Konwent dominikanów wrocławskich w późnym średniowieczu. PoznańWrocław 2008, s. 154-155; tenże, Szkoły i studia polskich dominikanów w okresie średniowiecza..., S. 21-22.

${ }^{23}$ Zob. J. Kłoczowski, Studium generalne dominikanów w Krakowie w XV wieku. W: tenże, Polska Prowincja Dominikańska w średniowieczu..., s. 254-255; tenże, Studia w polskiej prowincji dominikańskiej..., s. 265n.; K. Kaczmarek, Jeszcze o lektorach..., s. 77, 79, 80.

${ }^{24}$ Zob. J. Kłoczowski, Zakon dominikański i początki..., s. 246; zob. też M. Bukała, Dominikanie wrocławscy jako studenci $i$ wykładowcy studiów generalnych prowincji angielskiej $w$ pierwszej połowie XV w., „Śląski Kwartalnik Historyczny Sobótka” T. 55: 2000, nr 4, s. 557-558.

${ }^{25}$ Acta Capitulorum Provinciae Poloniae Ordinis Praedicatorum. Ed. F. Madura OP. Vol. 1: 1225160o. Romae 1972; J. A. Spież, Badania nad przeszłością dominikanów..., s. 31; zob. też uwagi odnośnie do tej kategorii źródeł - J. Kłoczowski, Klasztor dominikański w Lublinie w prowincji polskiej w XV-XVI stuleciu. W: Religie, edukacja, kultura. Ksiegga pamiątkowa dedykowana Profesorowi Stanisławowi Litakowi. Pod red. M. Surdackiego. Lublin 2002, s. 26-27; H. Gapski, Badania nad przeszłościa dominikanów..., s. 56; R. Świętochowski OP, Źródła do dziejów nowożytnych Zakonu Kaznodziejów..., s. 86.

${ }^{26}$ Zob. Acta Capitulorum Provinciae Poloniae Ordinis Praedicatorum. Ed. F. Madura OP. Vol. 2: a. 1603-170o, mszps Biblioteka oo. Dominikanów w Krakowie, sygn. 33429; zob. też Supplementum ex Registris litterarum magistrorum et procuratorum generalium OP. Ed. F. Madura OP. Vol. 3: a. 1608-1701. 
śnie do organizacji studiów w prowincji, troski o podniesienie poziomu kształcenia w krakowskim studium czy o nominacjach poszczególnych nauczycieli ${ }^{27}$.

$\mathrm{Z}$ punktu widzenia badań prozopograficznych lektura akt kapituł prowincjalnych odgrywa pierwszorzędne znaczenie ${ }^{28}$. Odnajdujemy bowiem w ich treści informacje o prowincjale, czterech definitorach, umieszczano w nich także wykazy magistrów, często także wykaz bakałarzy, kaznodziejów generalnych ${ }^{29}$. Dzięki temu ich analiza ułatwia śledzenie zachodzących zmian na poszczególnych urzędach, co umożliwia przeprowadzenie charakterystyki przebiegu kariery poszczególnych zakonników. Nie do przecenienia są również petycje zapisywane w aktach kapitulnych. Zawierają one wykazy zakonników zgłaszanych do objęcia stopni naukowych. Nierzadko szczegółowo uzasadniano ich osiągnięcia, wymieniając choćby odbyte studia. Ten dział w aktach kapitulnych ulegał stopniowemu rozszerzeniu, pojawiają się tam np. prośby kierowane do władz zakonnych o zgodę na druk książki ${ }^{30}$. Zapisy te w sposób wyjątkowo istotny uzupełniają obraz rozwoju kultury i nauki w konwencie.

Omawiając źródła do dziejów studium generale, nie można oczywiście pominąć najważniejszych pomników dominikańskiej historiografii ${ }^{11}$, prac Abrahama Bzowskiego czy Michała Siejkowskiego. Nie straciły również na aktualności ustalenia ojca Sadoka Barącza ${ }^{32}$.

${ }^{27}$ J. Kłoczowski, Prowincja w wiekach średnich. W: tenże, Polska Prowincja Dominikańska $w$ średniowieczu..., s. 22-23; zob. też uwagi - tenże, Zakon dominikański i początki..., s. 238; K. Kaczmarek, Konwent dominikanów wrocławskich..., s. 173n.; por. charakterystykę systemu edukacji opartą w znacznej mierze na aktach kapituł - J. Kłoczowski, Studia w polskiej prowincji dominikańskiej za prowincjalatu Jakuba z Bydgoszczy. W: tenże, Polska Prowincja Dominikańska w średniowieczu..., s. 263n.; zob. też tenże, Kształcenie w polskiej prowincji dominikańskiej w początkach XVI wieku. W: Tamże, s. 28on.; tenże, Wielki zakon XVII-wiecznej Rzeczypospolitej u progu swego rozwoju. Dominikanie polscy w świetle wizytacji generalnej z lat 1617-1619. W: Tamże, s. 373-374.

${ }_{28}$ Zob. też charakterystykę znaczenia tej kategorii źródeł - K. Kaczmarek, Szkoły i studia polskich dominikanów w okresie średniowiecza..., s. 17-23; zob. też M. Miławicki OP, W. Szymborski, „Vir sapientiae et morum probitate clarus”..., s. 128-129.

${ }_{29}$ Zob. uwagi - J. Kłoczowski, Kapituły Polskiej Prowincji Dominikańskiej w czasach saskich (1697-1772/1773). W: tenże, Polska Prowincja Dominikańska w średniowieczu..., s. 443; K. Kaczmarek, Konwent dominikanów wrocławskich..., s. 82-83.

3o Zob. J. Kłoczowski, Kapituły Polskiej Prowincji Dominikańskiej w czasach saskich..., s. 443-444.

${ }^{31}$ Skrótowy przegląd najważniejszych pomników nowożytnej polskiej historiografii dominikańskiej zamieszcza H. Gapski, Dominikanie w Lublinie. Zarys historiograficzny. W: Dominikanie w Lublinie. Studia z dziejów i kultury. Pod red. H. Gapskiego. Lublin 2006, s. 9-12.

${ }^{32} \mathrm{Z}$ punktu widzenia poniższych rozważań najważniejsze znaczenie ma drugi tom jego pomnikowej rozprawy - S. Barącz, Rys dziejów Zakonu Kaznodziejskiego w Polsce. T. 2. Lwów 1861; 
Najistotniejszy zrąb źródeł rękopiśmiennych do dziejów studium generale przechowywany jest w Archiwum Polskiej Prowincji Dominikanów w Krakowie. Wśród nich na szczególną uwagę zasługuje rękopis zatytułowany Liber Studii Generalis cracoviensis ${ }^{33}$. Znajdują się tam wpisy począwszy od roku 1519 aż po $1842^{34}$. Należy jednakże pamiętać, że rękopis ten powstał w XVIII wieku, z tego okresu zapisy są najbardziej wiarygodne. Wcześniejsze wpisy pochodzą z bliżej nieustalonych notatek. Stąd tak pilnym postulatem badawczym pozostaje analiza kodykologiczna kodeksu.

Wzmiankowany postulat weryfikacji zapisów znajdujących się w Liber studii możliwy jest dzięki istnieniu szeregu dalszych źródeł uzupełniających wiedzę o funkcjonowaniu konwentu. W proponowanych badaniach prozopograficznych należy koniecznie uwzględnić księgę profesji ${ }^{35}$. W rękopisie o sygnaturze ADK, $\mathrm{Kr} 9$ autorstwa Waleriana Litwanidesa ${ }^{36}$ odnotowywano $\mathrm{w}$ formule wpisu imię, nazwisko, dokładną datę złożonej profesji wedle układu: rok, miesiąc, dzień. Następne rubryki określały przełożonych zakonu - generała, prowincjała i przełożonego domu, w ostatniej rubryce umieszczano nazwisko magistra nowicjatu ${ }^{37}$. Wartość źródłową tej księgi podnoszą liczne dopiski, umieszczane

bezcennych informacji dostarcza także praca Catalogus Patrum et Fratrum sacri Ordinis Praedicatorum in Polonia, Russia et Magno Ducatu Lithvaniae Morturorum, conscriptus per Fr. Sadocum Barącz OP, 1887 Archiwum Polskiej Prowincji Dominikanów w Krakowie, Pr 35.

${ }_{33}$ Wstępne pobieżne informacje odnośnie do zawartości tego kodeksu zawiera praca M. Miławicki OP, W. Szymborski, „Vir sapientiae et morum probitate clarus”..., s. 128; zob. też R. Świętochowski OP, Źródła do dziejów nowożytnych Zakonu Kaznodziejów..., s. 89.

${ }^{34}$ Archiwum Polskiej Prowincji Dominikanów w Krakowie, Kr 20.

${ }^{35}$ Odnośnie do zachowanych nowożytnych ksiąg profesji krakowskich konwentów zob. uwagi - H. Gapski, Profesi dominikańscy..., s. 648n.; tenże, Rekrutacja do zakonów męskich w Polsce..., s. 10-11; por. tenże, Klasztory krakowskie w końcu XVI..., s. 12-13; zob. też najnowsze ustalenia dotyczące lwowskiej księgi profesji - T. Shevchenko, Rusini w zakonie dominikańskim (koniec XVI 1 połowa XVII wieku). W: Dominikanie na ziemiach polskich w epoce nowożytnej. Pod red. A. Markiewicz, M. Miławickiego OP. Kraków 2009, s. 170-191; odnośnie do formuł profesji składanych przez dominikanów zob. szerzej ustalenia - A. H. Thomas, La profession religieuse des dominicains. Formule, cérémonies, histoire. „Archivum Fratrum Praedicatorum” T. 39: 1969, s. 5-52.

${ }^{36}$ Archiwum Polskiej Prowincji Dominikanów w Krakowie, Kr 9: D.O.M. Catalogus Fratrum Profitentium in Conventu SSmae Trinitatis O.P. ab Anno Domini 1509 Cura R. P. F. Erasmi Coniussovii S. T. M. Prioris Cracoviensis Renovatus 1656; odnośnie do postaci autora tegoż rękopisu zob. R. Świętochowski, Litwanides (Litus, Litwinkowicz, Adryanowic mylnie Andrzejowicz) Bartłomiej, imię zakonne Walerian. W: Polski słownik biograficzny. Wrocław 1972, s. 487-488.

${ }^{37}$ Archiwum Polskiej Prowincji Dominikanów w Krakowie, Kr 9; H. Gapski, Profesi dominikańscy..., s. 650. 
przy nazwiskach zakonników, niejednokrotnie wyraźnie późniejszą ręką. Uzupełniają one informacje o zakonnikach. W ich treści odnaleźć można bowiem wpisy charakteryzujące ich udział $\mathrm{w}$ istotnych wydarzeniach z życia konwentu, pełnionych urzędach i funkcjach w zakonie. Księga profesji w pełni zasługuje na pogłębione studium, dokładną analizę paleograficzną poszczególnych rąk dokonujących wpisów. Dzięki takim badaniom będzie możliwe ustalenie, ilu zakonników wpisało się własnoręcznie, kto dokonywał wpisów do księgi prócz magistra nowicjatu, jak i czy istniał klucz, wedle którego dodawano następnie informacje o zakonnikach ${ }^{38}$.

Kontrolowanie wiarygodności zapisów w Liber studii umożliwi także lektura ksiąg rad prowincji ${ }^{39}$ oraz rad klasztoru krakowskiego ${ }^{40}$. Pojawiające się wzmianki o zatwierdzeniach poszczególnych urzędów czy nominacji ułatwią prace przy sporządzaniu spisów zakonników zaangażowanych w prace studium. Podobną funkcję spełnią wszelkie spisy zakonnikó $w^{41}$ czy sporządzone nekrologi ${ }^{42}$. Należy także sięgnąć do zachowanych klasztornych kopiariuszy ${ }^{43}$. Testacja dokumentów znacząco uzupełni obraz formułowanych spisów.

Kończąc ten pobieżny przegląd najważniejszych źródeł do dziejów krakowskiego studium generale, należy wspomnieć o pewnej kategorii rękopisów proweniencji niedominikańskiej, są nimi księgi święceń. W postulowanych badaniach są one niezwykle przydatne, gdyż zawierają następujące wpisy: datę i miejsce ordynacji, nazwisko biskupa udzielającego święceń, imię i nazwisko zakonnika wraz z przynależnością do wspólnoty zakonnej, czasem imię ojca or-

${ }^{38}$ Zob. wstępne ustalenia - H. Gapski, Rekrutacja do zakonów męskich w Polsce..., s. 148-149; tenże, Profesi dominikańscy..., s. 651-653, 672-673.

${ }_{39}$ Archiwum Polskiej Prowincji Dominikanów w Krakowie, PP. 37, 155, 38; M. Miławicki OP, W. Szymborski, „Vir sapientiae et morum probitate clarus”..., s. 129.

${ }^{40}$ Archiwum Polskiej Prowincji Dominikanów w Krakowie, Kr 10, Kr 11; M. Miławicki OP, W. Szymborski, „Vir sapientiae et morum probitate clarus” ..., s. 129.

${ }^{41}$ R. Świętochowski OP, Źródła do dziejów nowożytnych Zakonu Kaznodziejów..., s. 88-89; M. Miławicki OP, W. Szymborski, „Vir sapientiae et morum probitate clarus” ..., s. 128.

${ }^{42}$ R. Świętochowski OP, Źródła do dziejów nowożytnych Zakonu Kaznodziejów..., s. 87-88; K. Kaczmarek, Szkoły i studia polskich dominikanów w okresie średniowiecza..., s. 24, 44.

${ }^{43}$ Archiwum Polskiej Prowincji Dominikanów w Krakowie, Kr 1; Kr 2; Kr 3; Kr 4; odnośnie do przechowywanych w Archiwum Polskiej Prowincji Dominikanów w Krakowie kopiariuszy zob. też uwagi - W. Müller, Kopiariusze konwentów dominikańskich w Archiwum OO. Dominikanów w Krakowie. „Sprawozdania z Czynności Wydawniczej i Posiedzeń Naukowych oraz Kronika Towarzystwa Naukowego Katolickiego Uniwersytetu Lubelskiego" 1961, nr 11 za okres od 1 I 1960 do 31 XII 1960, s. 98-101. 
dynowanego. Wykazy święconych stanowią wyjątkowo użyteczne źródło przy badaniach nad prozopografią zakonną, gdyż nie tylko, jak wykazały prace ks. Jana Szczepaniaka, podawały nazwę macierzystego klasztoru danego zakonnika, lecz także nazwę konwentu, do którego dana osoba została przeniesiona w okresie pomiędzy święceniami ${ }^{44}$.

W oparciu o lekturę wspominanych wyżej źródeł można pokusić się o sformułowanie programu dalszych badań studium generale. Najważniejszy postulat badawczy wytyczył najwybitniejszy współcześnie żyjący polski badacz dziejów zakonów mendykanckich Jerzy Kłoczowski, a jest nim: „Wszechstronna analiza wspólnot dominikańskich, ludzi wchodzących w ich skład, pochodzenie, formacji, «dróg» wewnątrz zakonnych itd. pozostaje, oczywiście, wyzwaniem badawczym podstawowego znaczenia"45.

Próbując zrealizować powyższy postulat, chciałbym zwrócić uwagę na konieczność prześledzenia następujących kwestii związanych z dziejami krakowskiego studium generale. Zdaniem piszącego dzięki analizie poniższych zagadnień, przy zastosowaniu metody prozopograficznej ${ }^{46}$, choćby częściowo uda się zrealizować niezwykle szeroko wytyczony przez Jerzego Kłoczowskiego program badań nad zakonem braci kaznodziejów w epoce nowożytnej. Na potrzeby poniższych rozważań przyjęto schemat omawiania postulatów związanych z:

- składem osobowym,

- kulturą intelektualną,

- zagadnieniami prawnymi związanymi ze szkolnictwem zakonnym,

${ }^{44}$ Zob. szerzej J. Szczepaniak, Dominikanie w XVII-wiecznych krakowskich wykazach święceń. W: Historicus Polonus-Hungarus. Ksiega pamiątkowa ofiarowana Ojcu Józefowi Puciłowskiemu OP $w$ siedemdziesiątą rocznicę urodzin. Pod red. T. Gałuszki OP, P. Attili Illesa, M. Miławickiego OP, B. Zágorhidiego Czigánya. Kraków 2010, s. 591-639.

${ }^{45}$ J. Kłoczowski, Jak badań historię dominikanów w Polsce przedrozbiorowej? Trochę uwag i obserwacji co do znaczenia i programu przyszłych badań oraz ich miejsca w historiografii polskiej. W: Dzieje dominikanów w Polsce XIII-XVIII wiek..., s. 17; postulat konieczności podjęcia pilnych badań nad składem społecznym poszczególnych klasztorów Jerzy Kłoczowski zgłaszał począwszy od lat 50. XX w. Zob. przykładowo referat wygłoszony w 1952 r. - J. Kłoczowski, Prowincja w wiekach średnich. W: tenże, Polska Prowincja Dominikańska w średniowieczu..., s. 19n.

${ }^{46}$ Odnośnie do badań prozopograficznych zob. szerzej M. Zdanek, Regensi dominikańskiego..., s. 79; M. Miławicki OP, W. Szymborski, „Vir sapientiae et morum probitate clarus” ..., s. 127; zob. też uwagi o znaczeniu badań prozopograficznych w badaniach nad historią zakonu dominikańskiego - A. Pobóg-Lenartowicz, Stan i perspektywy badań nad dominikanami w Polsce (ze szczególnym uwzględnieniem Śląska). W: Dzieje dominikanów w Polsce XIII-XVIII wiek..., s. 72; K. Kaczmarek, Studia nad historią dominikanów w Polsce. Stan i kierunki badań - głos w dyskusji. W: tamże, s. 145. 
- relacjami pomiędzy uniwersytetem w Krakowie a studium dominikańskim,

- aktywnością zakonników w życiu kościelnym i państwowym.

Bezsprzecznie najważniejszym zadaniem badaczy przedmiotowej tematyki jest ustalenie katalogu wszystkich zakonników zaangażowanych w działalność studium generale. Pierwsze kroki w tym kierunku zostały poczynione, dysponujemy bowiem opracowanym katalogiem regensów, stojących na czele studium. Przyjmując zbliżony kwestionariusz badawczy, należy opracować spisy bakałarzy studium, mistrzów studentatu, bakałarzy prezentatów teologii. Warto zaznaczyć, że w tzw. Liber studii znajdują się takowe wykazy, prowadzone są one najczęściej od schyłku XVI aż po wiek XVIII. Wykazy te były prowadzone dość dokładnie, aczkolwiek należy dokonać ich weryfikacji, gdyż jak pokazały prace przy katalogu regensów, niejednokrotnie podawane daty stały w sprzeczności z innymi źródłami dominikańskimi.

Dopiero po ustaleniu takowych katalogów możliwe będą dalsze prace związane z całościowym spojrzeniem na zagadnienia związane z karierami zakonnymi. Warto pokusić się o próbę sporządzenia wykazu wszystkich studentów podejmujących naukę w krakowskim klasztorze ${ }^{47}$. Realizacja powyższych założeń pozwoliłaby na opracowanie rozbudowanego „spisu urzędników dominikańskich”. W powiązaniu z katalogiem klasztorów dominikańskich, którego pilną potrzebę sporządzenia zgłaszał Dariusz Dekański czy Rafał Witkowski ${ }^{48}$, znacząco wypełniłoby to lukę w badaniach nad składem społecznym klasztorów dominikańskich.

Analiza spisów zakonników zaangażowanych w dzieje funkcjonowania studium generale nie byłaby pełna bez uwzględnienia istotnego aspektu ich zaangażowania w życie prowincji, jak i klasztoru ${ }^{49}$. Znajdą wówczas potwierdzenie tezy stawiane choćby przez Jerzego Kłoczowskiego, analizującego szesnastowieczne akta kapituł i składy definitorów, odnośnie do wpływu zdobytego wykształcenia na dalsze losy i karierę zakonnika ${ }^{50}$. Dzięki temu badania te częściowo wypeł-

${ }^{47}$ Wzorców i kwestionariuszy badawczych mogą dostarczyć prace: M. Zdanek, Szkoły i studia dominikanów..., s. 166n.; K. Kaczmarek, Szkoły i studia polskich dominikanów..., passim; M. Miławicki OP, W. Szymborski, „Vir sapientiae et morum probitate clarus”..., s. 127.

${ }^{48}$ D. Dekański, Kilka uwag o dominikanach na Pomorzu Gdańskim i w państwie zakonu krzyżackiego w Prusach okresu średniowiecza $z$ uwzględnieniem propozycji badań $i$ ich koordynacji. W: Dzieje dominikanów w Polsce XIII-XVIII wiek..., s. 99.

${ }_{49}$ Zob. wstępne ustalenia odnośnie do aktywności zakonnej regensów - M. Miławicki OP, W. Szymborski, „Vir sapientiae et morum probitate clarus”..., s. $151 \mathrm{n}$.

5o J. Kłoczowski, Kształcenie w polskiej prowincji dominikańskiej w początkach XVI wieku. W: tenże, Polska Prowincja Dominikańska w średniowieczu..., s. 280; tenże, Wielki zakon XVII- 
nią postulat sformułowany przez Henryka Gapskiego: „Odczuwa się natomiast brak badań dotyczących osób sprawujących ważne funkcje zakonne prowincjałów i przeorów, jak również szerszych zjawisk kształtowania się władzy zarówno w sensie formalnym, jak i nieformalnym [...]" ${ }^{51}$.

Kolejnym aspektem, na jaki należy zwrócić uwagę, omawiając kariery zakonne, jest sprawa podejmowanych studiów poza granicami prowincji. Należałoby wzorem ustaleń Jerzego Kłoczowskiego odnośnie do pierwszej ćwierci XVI wieku prześledzić, czy osoby kierowane na dalsze studia odbyły nie tylko studia partykularne, ale również czy posiadały znaczący staż nauczycielski i duszpasterski ${ }^{52}$. Ukazanie tych zagadnień umożliwi prześledzenie zjawiska wyjątkowej mobilności ówczesnych zakonników w obrębie prowincji.

Całościowe spojrzenie na personel nauczający w krakowskim klasztorze pozwoli na zweryfikowanie wielu funkcjonujących w historiografii hipotez. Dokładna analiza karier zakonnych krakowskich magistrów potwierdzi bądź obali słowa Ojca Damiana a Fonseca, który przeprowadzając wizytację prowincji, stwierdził w 1619 roku, że to w tym klasztorze wykształcili się prawie wszyscy najwybitniejsi dominikanie w Polsce, tam także najżarliwiej zwalczano herezję i wyznania reformowane ${ }^{53}$. Przy tej okazji być może uda się także ustalić, na ile spór pomiędzy pozostałymi konwentami a krakowską Św. Trójcą był ważny dla życia wewnętrznego prowincji. Biorąc pod uwagę, że oparł się on aż o obrady kapituły generalnej w Rzymie w 1608 i 1612 roku $^{54}$, można do-

-wiecznej Rzeczypospolitej..., s. 379-38o; zob. też uwagi - K. Kaczmarek, Konwent dominikanów wrocławskich..., s. 102-103; tenże, Szkoły i studia polskich dominikanów w okresie średniowiecza..., s. 131-134; M. Zdanek, Regensi dominikańskiego..., s. 85; zob. też K. Stopka, Szkoła zakonna..., S. $58-59$.

${ }^{51}$ H. Gapski, Badania nad przeszłością dominikanów..., s. 60.

${ }^{2}$ J. Kłoczowski, Kształcenie w polskiej prowincji dominikańskiej..., s. 284n.; zob. ustalenia odnośnie do funkcjonowania zakonnego studium - tenże, Studia w polskiej prowincji dominikańskiej..., tabele nr 2-5, s. 266-269; zob. też G. Zonenberg, Ślązacy z polskiej prowincji dominikańskiej na studiach w Wiedniu w XV i na początku XVI wieku. „Studia Źródłoznawcze” T. 43: 2005, s. 113n.; postulat analizy karier zakonników w obrębie poszczególnych klasztorów zgłaszał między innymi R. Kubicki, Przeorzy konwentu gdańskiego od początków XIV w. do 1525. Przyczynek do badań nad składem osobowym konwentów kontraty pruskiej dominikanów w średniowieczu. W: Dominikanie: Gdańsk - Polska - Europa..., s. 201-202.

${ }^{53}$ Zob. J. Kłoczowski, Wielki zakon XVII-wiecznej Rzeczypospolitej..., s. 378; odnośnie do tez o przewadze konwentu krakowskiego zob. też P. Stolarski, Friars on the Frontier..., s. 54n.; R. Świętochowski OP, A. Chruszczewski, Polonia Dominicana apud extraneos..., passim.

${ }^{54}$ Zob. J. Kłoczowski, Wielki zakon XVII-wiecznej Rzeczypospolitej..., s. 381-382. 
mniemywać, iż spór ten był dość istotny, jednak nie posiadamy dokładnych ustaleń na ten temat.

Dysponując już wstępnymi ustaleniami dotyczącymi składu osobowego krakowskiego konwentu, można będzie pokusić się o próbę podsumowania dorobku intelektualnego kadry nauczającej. Warto w tym miejscu przytoczyć opinię Wacława Bucichowskiego: „Ustalenie możliwie pełnej listy dominikanów prowincji polskiej posiadających wykształcenie filozoficzne i teologiczne na poziomie uniwersyteckim jest nieodzownym warunkiem wszelkich dalszych badań nad kulturą umysłową dominikanów polskich w średniowie$\mathrm{czu}{ }^{55}$. Postulat jak najszerzej zakrojonych badań nad kulturą intelektualną zakonników od lat zgłasza również Jerzy Kłoczowski ${ }^{56}$. Ostatnio program badań księgozbiorów dominikańskich oraz rękopisów wykorzystywanych w toku zakonnej edukacji sformułował Krzysztof Ożóg57. Lektura akt kapituł przynosi szereg informacji dotyczących poleceń stosowania nowych podręczników przy nauczaniu poszczególnych przedmiotów, wypada skonfrontować te zalecenia z zachowanymi starodrukami i zbiorami rękopiśmiennymi. Zważyć jednak należy na fakt zniszczeń, jakich doznały zbiory biblioteczne krakowskiego konwentu.

Następnie dostrzegana jest także potrzeba rewizji księgozbiorów bibliotecznych w poszukiwaniu dominikańskich rękopisów ${ }^{58}$. Analiza dorobku pisarskiego zakonników ${ }^{59}$ wyjaśni szereg kwestii związanych z funkcjonowaniem studium, takich

${ }_{55}$ W. Bucichowski, Lista lektorów dominikańskich..., s. 45; zob. też opinię - J. Flaga, Uczoność zakonów..., s. 265.

${ }^{56}$ J. Kłoczowski, Jak badać historię dominikanów..., s. 18-19.

${ }^{57}$ K. Ożóg, Uwagi o potrzebach i perspektywach..., s. 106-111; por. K. Stopka, Szkoła zakonna..., s. $57-58$.

${ }^{58}$ Zob. tekst będący wprowadzeniem do dalszych badań nad zagadnieniem księgozbiorów dominikańskich - K. Zawadzka, Ze źródet i stanu badań dotyczacych dawnych klasztornych bibliotek dominikanów w polskich prowincjach, „Nasza Przeszłość” T. 39: 1973, s. 213-228; zob. też I. Pietrzkiewicz, Biblioteki mendykantów krakowskich w okresie średniowiecza - stan i perspektywy badań. W: Mendykanci w średniowiecznym Krakowie. Pod red. K. Ożóga, T. Gałuszki OP, A. Zajchowskiej. Kraków 2008, s. 139n.; odnośnie do dziejów księgozbioru krakowskiego konwentu zob. R. Świętochowski OP, Biblioteka OO. Dominikanów w Krakowie. „Archiwa, Biblioteki i Muzea Kościelne” T. 33: 1976, s. 299-311; zob. też najnowsze uwagi - T. Gałuszka OP, W przededniu powstania Studium Generale. Nowe badania nad czternastowiecznym zachowanym księgozbiorem dominikanów krakowskich. „Przegląd Tomistyczny” T. 16: 2001, s. 25-42.

59 Dla przykładu warto wspomnieć o wyjątkowej aktywności pisarskiej jednego z regensów krakowskiego studium Mikołaja z Mościsk, zob. uwagi - W. Graczyk, XVI-wieczni uczeni 
jak np. zaangażowanie na rzecz bądź zwalczanie projektów tworzenia następnego studium generale $\mathrm{w}$ obrębie prowincji, polemik dotyczących kwestii powoływania nowych prowincji ${ }^{60}$. W tym celu niezbędne jest zestawienie wszystkich druków autorstwa zakonników związanych z krakowskim ośrodkiem. Konieczność przebadania ksiąg rachunków w celu wychwycenia prac pominiętych przez Bibliografię Estreichera zgłosił już ponad 37 lat temu ojciec Robert Świętochowski ${ }^{61}$. Opracowanie takiego katalogu uzupełni obraz aktywności zakonników na polu choćby zaangażowania w bieżące życie religijne prowincji, zakonu. Całościowe spojrzenie na dorobek pisarski zakonników, w tym zwłaszcza wszelkich panegiryków i druków ulotnych, ułatwi także określenie kręgu donatorów zakonu ${ }^{62}$.

Kolejna kategoria postulatów badawczych związana jest $\mathrm{z}$ wszelkimi zagadnieniami prawnymi dotyczącymi nowożytnego szkolnictwa dominikańskiego. Lektura akt kapituł umożliwi, jak wykazał Maciej Zdanek w odniesieniu do urzędu regensa ${ }^{63}$, określenie kompetencji, zakresu obowiązków oraz przemian, jakim podlegały poszczególne urzędy. Warto podkreślić, że jak dotąd temat ten całościowo podejmował jedynie ojciec Robert Świętochowski ${ }^{64}$. Sporządzenie postulowanych wyżej spisów umożliwi określenie ewentualnej specyfiki studiów zakonnych w krakowskim studium generale. Wstępne uwagi poczynił już ojciec Świętochowski, charakteryzując tzw. prawo równowagi i późniejsze prawo alternatywy, jakie posiadało studium w konwencie Św. Trójcy ${ }^{65}$, które między innymi decydowało o tak znaczącej roli Krakowa. Warto również zaakcentować pilną potrzebę przybliżenia przywilejów składających się na Corpus privilegiorum Studii Bononiensis, albowiem obdarowywano nimi studia generalne wszystkich prowincji. W związku z tym obowiązywały one także krakowski ośrodek. Pomi-

dominikańscy pochodzący z Mościsk i ich wkład w rozwój teologii polskiej. W: Święty Jacek i dziedzictwo dominikańskie. Pod red. E. Matei, A. Pobóg-Lenartowicz. Opole 2008, s. 199-201; K. Górski, Dzieje życia wewnętrznego dominikanów..., s. 82.

${ }_{60}$ Zob. R. Świętochowski OP, Szkolnictwo teologiczne dominikanów..., s. 226.

${ }^{61}$ Zob. tamże, s. 218-219.

${ }^{62}$ Zob. tamże, s. 223.

${ }^{63}$ Zob. szerzej charakterystykę urzędu regensa - M. Zdanek, Regensi dominikańskiego..., s. 7986. Należy przykładowo przeanalizować długość trwania kadencji poszczególnych urzędów - zob. R. Świętochowski OP, Szkolnictwo teologiczne dominikanów..., s. 214, 215; zob. też uwagi - M. Zdanek, Regensi dominikańskiego..., s. 104; M. Miławicki OP, W. Szymborski, „Vir sapientiae et morum probitate clarus"..., s. 136-137.

${ }^{64}$ R. Świętochowski OP, Szkolnictwo teologiczne dominikanów..., s. 213-230.

${ }_{55}$ Zob. tamże, s. 226-227; M. Miławicki OP, W. Szymborski, „Vir sapientiae et morum probitate clarus" ..., s. 131-132, 142. 
mo starań podejmowanych przez generalnych wizytatorów, takich jak Damian a Fonseca, Jan Spina czy Augustyn de Imola na rzecz ujednolicenia praw i przywilejów posiadanych przez prowincje, poszczególne z nich posiadały specyficzne dla siebie uprawnienia. O tzw. prawach zwyczajowych wspominają bowiem akta kapituł prowincjonalnych ${ }^{66}$.

Obraz funkcjonowania krakowskiego studium generale pozostałby niepełny, gdyby pominąć dwie kolejne grupy zagadnień. Do pierwszej z nich zaliczają się kwestie związane z relacjami pomiędzy szkołą klasztorną a uniwersytetem krakowskim. Analiza spisów zakonników w połączeniu z lekturą źródeł uniwersyteckich być może umożliwi wyjaśnienie aspektów związanych z rekrutacją kandydatów do zakonu braci kaznodziejów ${ }^{67}$. Warto jednakże pamiętać, że wobec częściowego zniszczenia metryki uniwersyteckiej wnioski te mogą być niepełne. Problem rekrutacji dominikańskiej będzie się wpisywać w szerszy nurt rozważań odnośnie do roli i znaczenia klasztorów we wspólnotach miejskich, jak i funkcjonowania tzw. okręgów klasztornych ${ }^{68}$.

Na szczególną uwagę zasługują dzieje bractwa akademickiego powołanego w 1621 roku w klasztorze braci kaznodziejów ${ }^{69}$. Wpisują się one w szerszy nurt

${ }^{66}$ Zob. R. Świętochowski OP, Szkolnictwo teologiczne dominikanów..., s. 226-227.

${ }^{67}$ Trudności w badaniach tego zagadnienia z racji charakteru samych źródeł przedstawił w odniesieniu do XV wieku K. Kaczmarek, Rekrutacja do zakonu dominikanów wśród studentów Uniwersytetu Krakowskiego w XV wieku. W: Mendykanci w średniowiecznym..., s. 181-197; M. Zdanek, Szkoły i studia dominikanów..., s. 122-146, 180-184; zob. też K. Kaczmarek, Szkoły i studia polskich dominikanów w okresie średniowiecza..., s. 86n., 350n.; tenże, Konwent dominikanów wrocławskich..., passim; waga i znaczenie badań nad rekrutacją zakonną od lat wielokrotnie podkreślana jest w literaturze przedmiotu jako ważki postulat badawczy. Zob. H. Gapski, Rekrutacja do zakonów męskich $w$ Polsce..., s. 16n.

${ }^{68}$ Zob. uwagi - J. Kłoczowski, Okreggi klasztorne w Polskiej Prowincji Dominikańskiej w średniowieczu. W: tenże, Polska Prowincja Dominikańska w średniowieczu..., s. 181n.; zob. też tenże, Zaplecze społeczne polskich dominikanów, ich pozycja w Kościele, państwie i społeczeństwie. W: tamże, s. 219n.; por. ustalenia dotyczące rekrutacji do środowisk zakonnych na terenie Krakowa - H. Gapski, Rekrutacja do zakonów męskich w Polsce..., rozdz. 2: Geografia rekrutacji zakonnej, s. 65n.

${ }_{69}$ Zob. dokument $\mathrm{z} 12$ października $1621 \mathrm{r}$. wystawiony przez przeora konwentu krakowskiego Erazma Koniuszewskiego - J. Muczkowski, Bractwa Jezuickie i akademickie w Krakowie. Kraków 1845, dodatek B, s. 92-93; por. H. Barycz, Historia szkół nowodworskich od założenia do reformy H. Kołłąaja. Kraków 1988, s. 121; W. Urban, Akademia Krakowska w dobie reformacji i wczesnej kontrreformacji (1549-1632). W: Dzieje Uniwersytetu Jagiellońskiego w latach 1364-1764. Pod red. K. Lepszego. T. 1. Kraków 1964, s. 279; K. Gumol, Oratorium Św. Różańca Akademii Krakowskiej czyli Akademickie Bractwo Różańcowe u ojców dominikanów. „Rocznik Teologiczny Śląska Opolskiego" T. 1: 1968, s. 168n.; tenże, Duszpasterstwo Akademickie na Uniwersytecie Jagiellońskim w latach 
relacji uniwersytecko-dominikańskich datujących się od lat pięćdziesiątych $\mathrm{XV}$ wieku. Stanowią także interesujący przyczynek do badań nad stosunkami panującymi pomiędzy dominikanami a jezuitami w okresie, gdy uniwersytet toczył zaciekłe walki z Towarzystwem Jezusowym. Lektura zachowanych akt bractwa różańcowego, ksiąg rad klasztornych umożliwi pełniejsze spojrzenie na związki pomiędzy uniwersytetem a bractwem, pozwoli także wyjaśnić, dlaczego bractwo tak szybko zostało przeniesione do kościoła karmelitów bosych ${ }^{70}$.

Ponadto stosunki panujące pomiędzy dominikańskim studium generale a uniwersytetem wpisują się w nurt rozważań dotyczącej aktywności zakonników w szeroko pojmowanym życiu kościelnym i państwowym. Wypada tutaj bliżej przyjrzeć się karierom braci dominikanów i ich związkom z hierarchią kościelną. Studia takie podejmowano w odniesieniu do epoki średniowiecza i roli biskupów pomocniczych czy dominikańskich inkwizytorów ${ }^{71}$. W przypadku relacji pomiędzy zakonnikami a klerem świeckim warto zwrócić uwagę np. na kwestie obrony praw i przywilejów dominikańskich, jak choćby egzempcji ${ }^{22}$. Nie należy także zapominać o roli, jaką odgrywali bracia kaznodzieje w życiu państwa, pełniąc obowiązki choćby królewskich spowiedników ${ }^{73}$.

1400-1795. „Zeszyty Naukowe Katolickiego Uniwersytetu Lubelskiego” T. 7: 1964, nr 2 (26), s. 56, 62; P. Stolarski, Friars on the Frontier..., s. 33-37.

$7^{70}$ Zob. J. Muczkowski, Bractwa Jezuickie..., s. 15n.

${ }^{71}$ Zob. uwagi - J. Kłoczowski, Zaplecze społeczne polskich Dominikanów, ich pozycja w Kościele, państwie i społeczeństwie. W: tenże, Polska Prowincja Dominikańska $w$ średniowieczu..., s. 227-228; tenże, Zakon dominikański i początki..., s. 243; tenże, Kształcenie w polskiej prowincji dominikańskiej..., s. 283; tenże, Dominikanie w środkowo-wschodniej Europie i ich kultura intelektualna oraz pastoralna $w$ wiekach średnich. W: Dominikanie w środkowej Europie w XIII-XV wieku..., s. 163; zob. też K. Kaczmarek, Wykształcenie średniowiecznych inkwizytorów dominikańskich z ziem polskich. W: Inkwizycja papieska w Europie Środkowo-Wschodniej. Pod red. P. Krasa. Kraków 2010, s. 197-219; M. Zdanek, Inkwizytorzy dominikańscy w diecezji krakowskiej w średniowieczu. W: tamże, s. 219-235; P. Kras, Działalność inkwizycyjna dominikanów krakowskich w średniowieczu. W: Mendykanci w średniowiecznym Krakowie..., s. 383-407; tenże, Dominican Inquisitors in Mediaeval Poland. W: Praedicatores, Inquisitores - I. The Dominicans and the Mediaeval Inquisition. Acts of the 1st International Seminar on the Dominicans and the Inquisition. Rome, 23-25 February 2002. Ed. W. Hoyer. Roma 2004, s. 249-310.

${ }_{22}$ Zob. uwagi - R. Świętochowski, OP, Szkolnictwo teologiczne dominikanów..., s. 221.

${ }_{73}$ Zob. G. Głuch, Dominikańscy spowiednicy i kaznodzieje Jagiellonów. W: Dominikanie w środkowej Europie w XIII-XV wieku..., s. 239-258; U. Borkowska, Królewscy spowiednicy. W: Ludzie - Kościół - wierzenia. Studia z dziejów kultury i społeczeństwa Europy Środkowej (średniowiecze - wczesna epoka nowożytna). Pod red. W. Iwańczka, S. K. Kuczyńskiego. Warszawa 2001, s. 173-194. 
Kończąc tę skrótową listę postulatów badawczych, wypada podkreślić jeszcze jeden aspekt uzupełniający obraz dziejów studium generale. Opracowując jego historię, należy zwrócić uwagę na stan materialny krakowskiego konwentu. Jak wykazały wstępne ustalenia Macieja Zdanka czy Jerzego Kłoczowskiego, istniały ścisłe związki pomiędzy sytuacją gospodarczą klasztoru a okresem rozwoju, rozbudowy i upadku studium ${ }^{74}$. Postulat ten ściśle powiązany jest $\mathrm{z}$ kwestiami funkcjonowania okręgów dominikańskich ${ }^{75}$.

\section{Summary}

\section{Sources for the study of the history of the dominican studium generale in Krakow in the modern era. \\ The state of research and research perspectives}

Main objective of the essay under consideration was investigation and characterized most important source materials stocked at the Archive of the Cracow's Dominican Province to present the history of their studium generale during the Modern period. Also, the current knowledge of a.m. period of studium generale was screened- out and some searching hypothesis were proposed concerning the history of the Cracow's Do-

${ }_{74}$ M. Zdanek, Szkoły i studia dominikanów..., s. 87-92, 150-151; tenże, Regensi dominikańskiego..., s. 97-99; zob. też uwagi - K. Kaczmarek, Szkoły i studia polskich dominikanów w okresie średniowiecza..., s. 298-300; zob. szerzej ustalenia dotyczące dziejów gospodarczych konwentu krakowskiego - M. Zdanek, Kupno renty w gospodarce krakowskiego klasztoru dominikanów w XV i na początku XVI w. W: Mendykanci w średniowiecznym Krakowie..., s. 517-531; tenże, Dochody dominikanów krakowskich w 1. połowie XVI w. W: Inter oeconomiam coelestem et terrenam. Mendykanci a zagadnienia ekonomiczne. Pod red. W. Długokęckiego, T. Gałuszki OP, R. Kubickiego, A. Zajchowskiej. Kraków 2011, s. 259-277; M. Miławicki OP, Kształtowanie się własności ziemskiej klasztoru dominikanów w Krakowie w okresie przedrozbiorowym. W: tamże, s. 277-301; odnośnie do źródeł rachunkowych zob. R. Świętochowski OP, Źródła do dziejów nowożytnych Zakonu Kaznodziejów..., s. 87.

${ }^{75}$ Zob. J. Kłoczowski, Polska prowincja dominikańska za Zygmunta Augusta w świetle akt kapituł prowincjalnych. W: tenże, Polska Prowincja Dominikańska w średniowieczu..., s. 348. 
minican studium generale. The searching time frame have been limited to XVI up to XVII century. Taken into consideration, the current status of research works performed so far, one ought to stated that the Modern Epoch has not been searched out with the same consciousness compare to the Medieval one. As the most important printed source materials, one ought to account the documents issued by the general and provincial chapters of the Convent. The documents of the provincial chapters have been listed and screened by Father Fabian Madura, and were stocked as the typescript formats at the Cracow's Dominican Convent Library.

Based on the searched source materials of General Chapter of Dominican Convent at Cracow, it is possible to present the general overview of the convent education system and its changes in due time. Due to the records found it would be possible to identify - position and name - the Dominicans nominated to the Convent stadium generale.

The most important manuscript stocked at the Cracow's Dominican Convent Archive as the education system is concern, is so called Liber Studii Generalis cracoviensis (rkps 20). This manuscript covers the list of friars who have been nominated to work at stadium generale. A.m. document has to verify and compare with other sources.

Taken into consideration above mention facts, it seems to be as most important searching activities to describe the convent society of the Cracow's Dominicans. At the essay some detailed searching hypothesis were presented, such as searching and reviewing the personnel of studium generale, the convent, intellectual culture both teachers and scholar, legal aspects related to the convent's education system, links and cooperation between the Cracow's University and studium generale and the Dominicans activities both sacrum and profanum. 